\title{
PROTEROGYNOTAENIA DEBLOCKI SP. NOV. (CESTODA: PROGYNOTAENIIDAE) FROM THE RED-CAPPED PLOVER, CHARADRIUS RUFICAPILLUS, FROM KING ISLAND, TASMANIA
}

\author{
by John M. Kinsella and Albert G. Canaris \\ (with one text-figure)
}

\begin{abstract}
Kinsella, J. M., \& Canaris, A. G., 2003 (19:xii): Proterogynotaenia deblocki sp. nov. (Cestoda: Progynotaeniidae) from the Red-capped Plover, Charadrius ruficapillus, from King Island, Tasmania. Papers and Proceedings of the Royal Society of Tasmania 137: 13-15. https://doi.org/10.26749/rstpp.137.13 ISSN 0080-4703.

HelmWest Laboratory, 2108 Hilda Avenue, Missoula, Montana, USA 59801 (JMK*); and PO Box 717, Hamilton, Montana, USA 59840 (formerly Department of Biological Sciences, University of Texas at El Paso) (AGC). *Author for correspondence.
\end{abstract}

A new species of cestode, Proterogynotaenia deblocki (Progynotaeniidae), is described from the Red-capped Plover, Charadrius ruficapillus, from King Island, Tasmania. The new species is characterised by its longer strobila (18-28 mm), large number of proglottids (60-85), number and size of the hooks on the rostellum (six large hooks 33-39 $\mu \mathrm{m}$ long, six small hooks 13-15 $\mu \mathrm{m}$ long) and large number of testes (62-83), which are divided by the uterus into two groups.

Key Words: cestode, Proterogynotaenia deblocki, Charadrius ruficapillus, Red-Capped plover, King Island, Tasmania.

\section{INTRODUCTION}

The Red-capped Plover, Charadrius ruficapillus Temminck, 1822, is a non-migratory shorebird widespread in Australia, especially in the southern half, common in Tasmania, and occasionally reported from New Zealand. It is found in littoral, estuarine and terrestrial wetlands, especially in arid areas, and prefers saline and brackish waters, where it feeds on annelids, molluscs, small crustaceans and some plant material (Marchant \& Higgins 1993).

In an earlier paper, we reported on the helminth parasite communities of four species of shorebirds, including the Red-capped Plover on King Island, Tasmania (Canaris \& Kinsella 1998). The most prevalent helminth found in C. ruficapillus was an undescribed cestode of the genus Proterogynotaenia (17 of 20,85\%). Here we describe this new species.

\section{MATERIAL AND METHODS}

Red-capped Plovers ( $N=20)$ were collected on King Island, Tasmania, under appropriate permits from 26 February to 8 March 1993. Birds were immediately placed in individual plastic bags, refrigerated and examined within six hours. Cestodes were relaxed in cold tap water, fixed in alcoholformalin-acetic acid (AFA), stained in Semichon's acid carmine or Ehrlich's hematoxylin, cleared in clove oil and mounted in Canada balsam. Some scoleces were squashed and mounted in Hoyer's medium to obtain a more accurate measurement of the rostellar hooks. Data provided are ranges followed by means in parentheses. Measurements are in micrometres unless otherwise specified. Type specimens were deposited in the Helminth Collection of the South Australian Museum, Adelaide, Australia, and the United States National Parasite Collection, Beltsville, Maryland, USA.
TAXONOMY

\section{Proterogynotaenia deblocki sp. nov. Fig. 1A-E}

\section{Description based on ten mature specimens}

Gravid cestodes 18-28 (23) mm long, craspedote, apolytic, consisting of 60-85 (71) proglottids. Scolex (fig. 1A) 162-195 (187) long by 220-300 (267) wide. Suckers oval, 120-150 (134) long by 95-105 (100) wide. Rostellum up to 160 long when completely everted, bearing 12 hooks of two sizes that alternate irregularly in two circles; anterior hooks 33-39 (37) long, posterior hooks 13-15 (14) long, both with long, slender handle and small blade and slightly shorter guard (fig. 1B). Rostellar sac 160-265 (200) long by 60-80 (70) in maximum width, extending to level of posterior margins of suckers or slightly beyond. Neck short, 120-160 (137). Two dorsal and two ventral osmoregulatory canals with transverse connections in posterior end of each proglottid. Strobila proterogynous, develops very slowly; in one specimen with 67 proglottids, ovary and vitellarium first appear in proglottid 54 and are completely developed in proglottid 56; large seminal receptacle up to 240 in diameter appears in following proglottid while ovary disintegrates. Seminal receptacle, in turn, atrophies in next proglottid, but remnant can be seen in terminal proglottids. Ovary lobulate, composed of two posteriorly directed lobes joined by an anterior isthmus, 205-255 (228) long (fig. 1C). Vitellarium posterior to ovary and often surrounded by branches of ovary, rounded, 60-80 (73) in diameter. Testes mature in the next 3-4 proglottids after ovary disappears. Proglottids with fully mature testes and developing uterus 1070-1220 (1147) long by 590-970 (804) wide (fig. 1D). Testes arranged in two groups, separated by uterus, 24-35 (27) poral, and 39-56 (46) antiporal; total number ranges from 62-83 (74). Mature testes roughly spherical, 55-73 (59) in maximum diameter. Cirrus pouch in anterior half of proglottid, passing between longitudinal excretory canals, 440-545 long (453) by 120-150 (132) in maximum width. Coiled external and internal seminal vesicles present. Cirrus stout, strongly muscular, when fully everted is proximally 

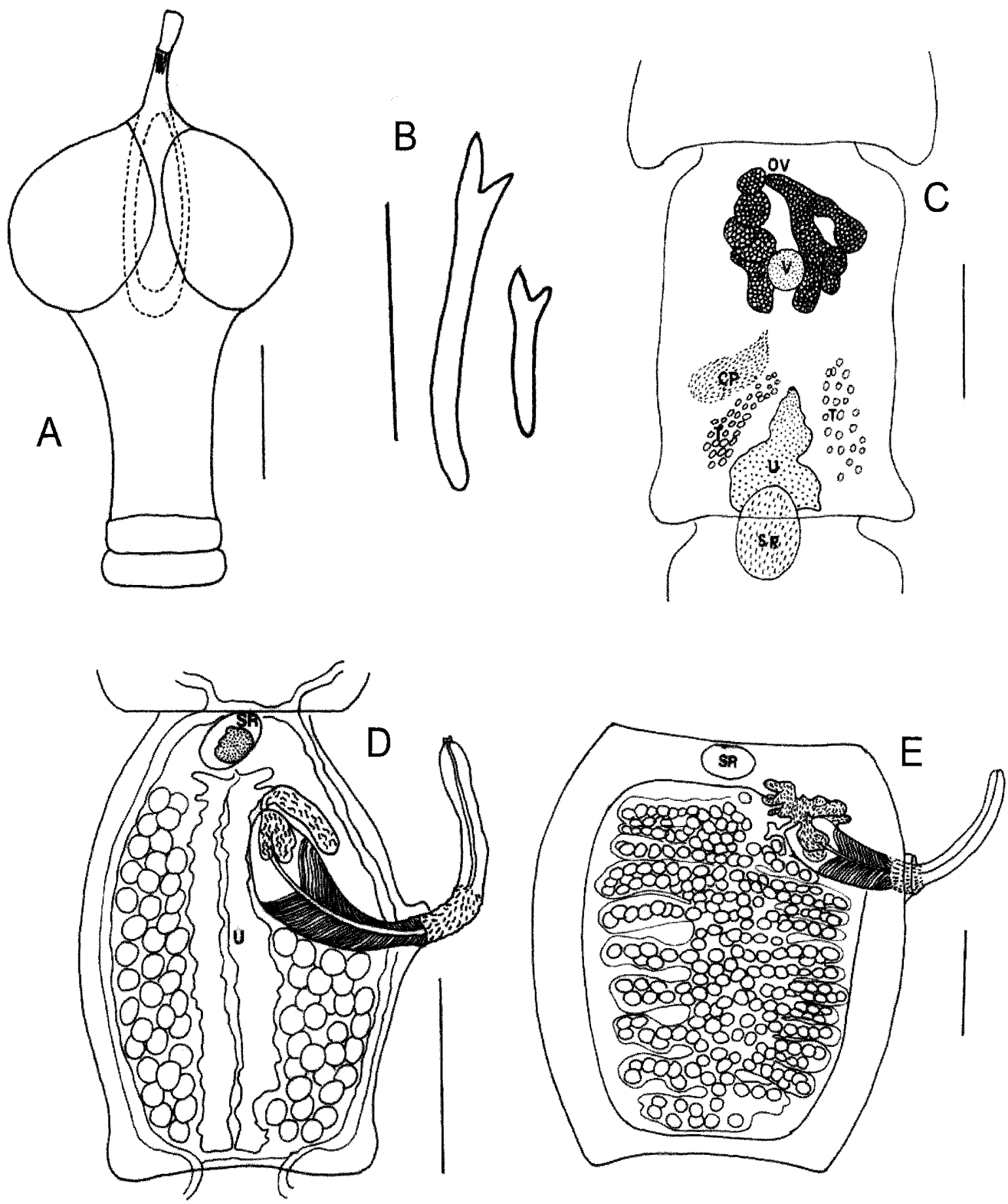

FIG. I - Proterogynotaenia deblocki sp. nov. (A) Scolex and rostellum; (B) Rostellar hooks; (C) Proglottid with ovary and vitellarium developed; (D) Mature proglottid with testes, cirrus, and uterus developed; (E) Gravid proglottid. $C P=$ developing cirrus pouch, $O V=$ ovary, $S R=$ seminal receptacle, $T=$ testes, $V=$ vitellarium, $U=$ uterus. Scales: (A) $100 \mu \mathrm{m}$. (B) $25 \mu \mathrm{m}$. (C) $500 \mu \mathrm{m}$. (D) $250 \mu \mathrm{m}$. (E) $500 \mu \mathrm{m}$.

spined for first third and smooth distally, 410-505 (453) long (measuring from base of spines to end), projects from a genital papilla (fig. 1D). Genital pores irregularly alternating. In most specimens, only terminal proglottid has completely mature eggs. Gravid proglottids large (fig. $1 \mathrm{E}$ ), about twice as long as wide, 1685-2245 (1982) by 860-1225 (991), uterus a median tube with 10-15 lateral branches on each side. Eggs round, 36-45 (41) in diameter, oncospheral hooks 10-12 in length.
Type host

Charadrius ruficapillus Temminck, 1822, Red-capped Plover.

Site of infection

Small intestine.

Prevalence and intensity

17 of $20(85 \%)$ infected with 2-149 (mean 34). 
Type locality

King Island, Tasmania.

Type specimens

Helminth Collection of the South Australian Museum, holotype No. 28529, paratypes Nos 28530-28532; U.S. National Parasite Collection, paratype No. 93985.

\section{Etymology}

Named in honour of Dr Stephane Deblock for his many contributions to the systematics of cestodes.

\section{DISCUSSION}

There are currently 12 species recognised in the genus Proterogynotaenia: $P$. rouxi Fuhrmann, 1911; P. flaccida (Meggitt, 1928); P. haematopodis (Davies \& Rees, 1947); $P$. neoarctica Webster, 1951 ; $P$. variabilis Belopolskaya, 1953; P. dougi Sandeman, 1959; P. polytestis Belopolskaya, 1973; P. branchiuterina Belopolskaya, 1973; P. texanum Huey, 1985; P. marcusae Schmidt \& Canaris, 1992; P. paulinae Schmidt \& Canaris, 1992; and P. tibori Macko \& Spakulova, 1995. Ryzhikov \& Tolkacheva (1981) considered $P$. branchiuterina a synonym of $P$. dougi, but Macko \& Spakulova (1995) re-examined the type material of $P$. dougi and concluded that differences in the cirrus armature and uterine shape between the two species justified retaining P. branchiuterina as a separate species.

Species of Proterogynotaenia are generally distinguished by total length, number of proglottids, number and size of rostellar hooks, and the number and distribution of testes (poral and antiporal) (Schmidt \& Canaris 1992). Seven species ( $P$. flaccida, $P$ variabilis, $P$. dougi, $P$ polytestis, $P$. branchiuterina, $P$. texanum, $P$. tibori) are all less than $7 \mathrm{~mm}$ long, with a maximum of nine proglottids per gravid worm. Of the larger species, only two, $P$ rouxi $(15-20 \mathrm{~mm})$ and P. marcusuae (22-26 $\mathrm{mm}$ ), approach the length of gravid $P$. deblocki $(18-28 \mathrm{~mm})$. Proterogynotaenia marcusae has only 34-40 proglottids compared with $60-85$ in $P$. deblocki and the testes of $P$. marcusae are not divided into two fields by the uterus, making it unique in the genus. Proglottids of $P$. rouxi number from $63-70$, overlapping with $P$. deblocki, but the maximum reported length is $20 \mathrm{~mm}$. In addition, $P$. rouxi has seven large and seven small rostellar hooks compared with six large and six small hooks in $P$. deblocki. The number of testes in $P$. rouxi $(50)$ is also less than in P. deblocki (62-83).

The total number of hooks on the rostellum in this genus shows considerable variation, ranging from 12 in six species ( $P$. variabilis, $P$. polytestis, $P$. texanum, $P$ paulinae, $P$. marcusae, $P$ tibori) to as many as 68 in $P$. haematopodis. Three of the species with 12 hooks (P. polytestis, P. texanum, P. tibori) have hooks in the same size range (33-40 and 13-18) as $P$. deblocki (33-39 and 13-15), but all are much smaller worms, with a maximum of nine proglottids.

Only three species overlap $P$. deblocki in numbers of testes: $P$. haematopodis with 50-130 testes, P. marcusae with 50-70 testes and $P$. polytestis with 72 testes. The first two species have been differentiated from $P$ deblocki (see above); mature $P$. polytestis are differentiated from $P$. deblocki by having fewer proglottids (8) and a much shorter length $(2.2 \mathrm{~mm})$.
To date, each species of Proterogynotaenia is known only from one species of host. In an earlier study of four species of shorebirds from King Island, $P$. deblocki had high prevalence $(85 \%)$ in C. ruficapillus, but was absent in Masked Lapwings, Vanellus miles (Boddaert, 1782), Ruddy Turnstones, Arenaria interpres (Linnaeus, 1758), and Curlew Sandpipers, Calidris ferruginea (Pontoppidan, 1763) (Canaris \& Kinsella 1998). Six species of Proterogynotaenia ( $P$. variabilis, $P$. branchiuterina, $P$ dougi, $P$. polytestis, $P$. texanum, $P$. tibori) have been described from the same host, the Black-bellied Plover, Pluvialis squatarola (Linnaeus, 1758). More extensive collections from $P$. squatarola are needed to study the range of morphological variation and the validity of these species. Genetic studies would be particularly useful in answering these questions. It is important that future researchers preserve some specimens collected in ethanol for analysis of nucleic acid sequences.

It is noteworthy that the three species of Proterogynotaenia with the greatest lengths and largest numbers of proglottids are all from the southern hemisphere: $P$. marcusae from South Africa, $P$ rouxi from the Aru Islands and now $P$. deblocki from Tasmania. Again, genetic studies may show whether these species are closely related or if this is just a coincidence.

\section{ACKNOWLEDGEMENTS}

We wish to thank Nigel Burgess; Jamie Bayly-Stark, Assistant Director Wildlife; David Rounsevell, Wildlife Research Officer; Dr Steven Smith, Chief Zoologist, Department of Parks, Wildlife and Heritage, Tasmania; and Dr Michael Stoddart, University of Tasmania, for their help, courtesy and support in obtaining permits and collecting birds on King Island. Patricia A. Canaris assisted with fieldwork and prepared the final drawings.

\section{REFERENCES}

Canaris, A. G. \& Kinsella, J. M., 1998: Helminth parasite communities in four species of shorebirds (Charadriidae) on King Island, Tasmania. Papers and Proceedings of the Royal Society of Tasmania 132: 49-57.

Macko, J. K. \& Spakulova, M., 1995: Taxonomic study of some Proterogynotaenia tapeworms (Cestoda: Acoleata) from Pluvialis spp. (Charadriformes) including a description of $P$ tibori sp. n. and a redescription of $P$. dougi. Biologia, Bratislava 50: 449-455.

Marchant, S. \& Higgins, P. J. (Eds), 1993: Handbook of Australian, New Zealand, and Antarctic Birds. Vol. 2: Raptors to Lapuings. Oxford University Press, Melbourne: 984 pp.

Ryzhikov, K. M. \& Tolkacheva, L. M., 1981: Principles of Cestodology. Vol. 10. Acoleata-Cestodes of Birds. Academy of Sciences, Moscow. [In Russian.]

Schmidt, G. D. \& Canaris, A. G., 1992: Tapeworms of the families Progynotaeniidae Fuhrmann, 1936 and Dioecocestidae Southwell, 1930 from shorebirds of South Africa. Systematic Parasitology 23: 37-42.

(accepted 29 September 2003)) 